\title{
Diagnostyka i prognozowanie stanu węzla łożyskowego układu biegowego pojazdu szynowego
}

\begin{abstract}
$W$ artykule przedstawiono klasyfikacje badań diagnostycznych oraz opisano podstawowe metody prognozowania stanu maszyn. Przedstawiono charakterystyke węzła maźnicznego układu biegowego z wyszczególnieniem elementów składowych. Zaprezentowano kryteria m.in. temperaturowe, fizyko-chemiczne oraz eksploatacyjne tożysk oraz maźnic pojazdów trakcyjnych. Artykul zostal opracowany w ramach projektu badawczo-rozwojowego $\mathrm{Nr} 10004806$ pt. „Mikroprocesorowy system diagnostyczny głównych systemów trakcyjnego pojazdu szynowego uwzględniajacy ocenę bieżqca i prognozowanie stanów", finansowanego z budżetu Ministerstwa Nauki i Szkolnictwa Wyższego.
\end{abstract}

\section{WPROWADZENIE}

Układ biegowy pojazdu szynowego wywiera znaczny wpływ na bezpieczeństwo eksploatacyjne i własności dynamiczne pojazdu oraz współpracę pojazdu $\mathrm{z}$ torem dlatego tak ważne jest, aby wiele $\mathrm{z}$ jego głównych elementów i zespołów pracowało bezawaryjnie. $\mathrm{Z}$ powyższego wynika jak istotna jest bieżąca ocena stanu technicznego głównych zespołów układu biegowego do których można zaliczyć:

- zestawy kołowe

- łożyska osiowe i maźnice

- usprężynowanie I-go i II-go stopnia

- prowadzenie zestawów kołowych

- oparcie nadwozia pojazdu na wózkach

- układy przeniesienia sił hamujących i pociagowych

- układy powiązań międzywózkowych (np. sprzęg międzywózkowy).

W trakcie eksploatacji elementy układu biegowego ulegają zużywaniu się tzn. niszczeniu normalnemu oraz uszkadzaniu, które możemy uznać za niszczenie normalne. Procesy zużycia prowadzą do konkretnych uszkodzeń, o różnych skutkach dla całego układu biegowego. Jeśli nie zostaną wykryte i zatrzymane $\mathrm{w}$ porę, prowadzą do uszkodzeń całkowitych tj. awarii całego układu lub też jego elementu. Zużywanie się elementów układu biegowego następuje z różną intensywnością. Wynika z tego, że łatwiej jest mówić o jego zużyciu w odniesieniu do konkretnego obiektu.

Prawidłowe współdziałanie zestawów kołowych z torem, zwłaszcza w pojazdach przewidzianych do wysokich prędkości jazdy, zależy w dużym stopniu od rozwiązania węzłów łożyskowych. Istniejące konstrukcje tych węzłów umożliwiają uzyskiwanie coraz korzystniejszych własności dynamicznych wózków, zwiększenie bezpieczeństwa jazdy oraz poprawę warunków eksploatacji. Zadaniem węzłów łożyskowych jest: przenoszenie obciążeń pionowych $\mathrm{z}$ wózka na zestawy kołowe, a podczas jazdy przenoszenie z kół przez łożyska na ramę wózka poziomych sił wzdłużnych pociagowych i hamowania oraz sił poprzecznych, powstających głównie wskutek nierówności poprzecznych toru oraz jazdy pojazdu w tukach toru. Elementy składowe węzła łożyskowego przedstawiono na rys. 1.

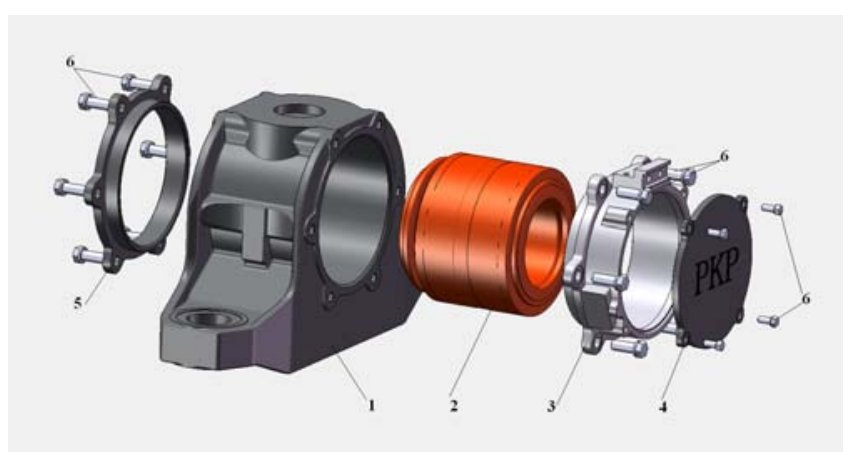

1 - korpus maźnicy; 2 - łożysko toczne wraz z uszczelnieniem; 3 piasta pośrednia;4 - pokrywa przednia; 5 - pokrywa tylna; 6 śruby mocujace

Rys. 1. Elementy składowe węzła łożyskowego pojazdu szynowego [1]

Z powyższego wynika, że węzeł łożyskowy jest jednym $z$ newralgicznych miejsc $w$ pojeździe, od stanu którego zależy prawidłowe funkcjonowanie pojazdu. $Z$ tego też względu istotne jest zagwarantowanie ciagłej i bezawaryjnej pracy łożyska poprzez zapewnienie optymalnych warunków pracy oraz prowadzenie ciagłego monitoringu stanu technicznego łożyska. Należy pamiętać, że uszkodzenia węzłów łożyskowych może być następstwem innych awarii. Dlatego też istotne jest, aby ocenie stanu technicznego węzła łożyskowego towarzyszyło określenie przyczyny uszkodzenia łożyska. 


\section{DIAGNOSTYKA I PROGNOZOWANIE}

\subsection{Badania diagnostyczne}

Badania diagnostyczne pojazdów szynowych można klasyfikować biorąc pod uwagę różne kryteria. Do najważniejszych należy zaliczyć poziom automatyzacji i czas trwania pomiarów.

Biorąc jako kryterium poziom automatyzacji można wyróżnić następujące kategorie [3]:

- badania manualne, podczas których rola człowieka polega na wykonywaniu czynności związanych z pomiarami, analizą oraz archiwizacją wyników, a także wizualizacją $\mathrm{i}$ formułowaniem oceny stanu technicznego

- badania na stanowiskach skomputeryzowanych, dzięki łatwej archiwizacji wyników, umożliwiają sporządzenie charakterystyk zmian parametrów diagnostycznych; jest to szczególnie istotne w przypadku badania szybkozmiennych parametrów diagnostycznych jak również wtedy, gdy ważny jest kształt charakterystyki ich zmian.

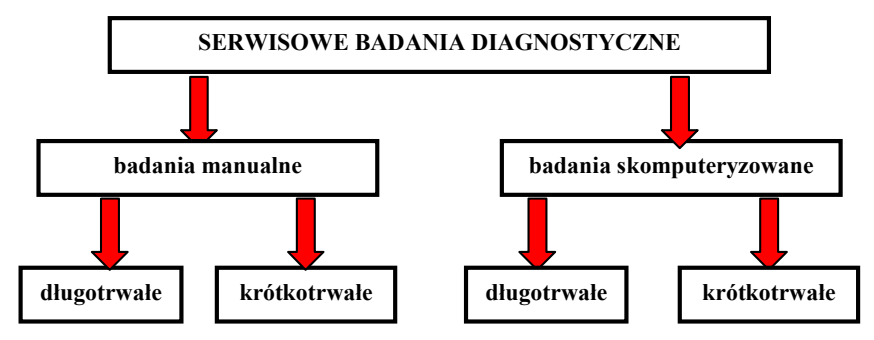

Rys. 2. Klasyfikacja serwisowych badań diagnostycznych [1]

Badania diagnostyczne charakteryzują się mnogością metod i środków. Podstawą oceny stanu technicznego pojazdu jest uzyskanie pomiarów wykonanych przy użyciu prostych urządzeń jak i tych bardziej skomplikowanych, ponieważ dopiero to daje nam obraz o badanym obiekcie i pozwala na opracowanie metody optymalizującej działanie danego układu.

Zastosowanie w procesie eksploatacji metod ozpoznawania stanu pojazdów i maszyn roboczych wymaga optymalizacji:

- zbioru parametrów diagnostycznych

- testów i programów diagnostycznych

- metod genezowania i metod prognozowania.

Rozwiązanie tych zadań zależy od wielu czynników związanych:

- ze stopniem złożoności maszyn

- z wykorzystaniem obserwacji wielosymptomowych

- $\quad$ z jakością procesu eksploatacji oraz procesu zużycia.

Rozpoznawanie stanu pojazdów i maszyn roboczych to proces, który ułatwia określenie technicznego stanu maszyny w czasie bieżącym na podstawie wyników badań diagnostycznych. Umożliwia to kontrolę a) zbioru parametrów diagnostycznych w zależności od czasu pracy maszyny, wartości kroku czasowego i liczebności optymalnego zbioru parametrów diagnostycznych;

b) metody wyznaczania testów i programów diagnostycznych w zależności od wiarygodności diagnozy, ilości informacji, prawdopodobieństwa uszkodzenia zespołów maszyny i kosztu testu lub programu diagnostycznego;

c) metody prognozowania $\mathrm{w}$ zależności od horyzontu prognozy, minimalnej liczby elementów szeregu czasowego niezbędnej do uruchomienia predykcji oraz czasu pracy maszyny.

d) metody genezowania $\mathrm{w}$ zależności od horyzontu genezy, minimalnej liczby elementów szeregu czasowego niezbędnej do uruchomienia genezy oraz czasu pracy maszyny.

Rozpoznanie stanu pojazdów, badanie dynamiki ich konstrukcji, wysokie wymagania odnośnie sprawności oraz przepisy prawne dotyczące bezpieczeństwa i ochrony środowiska decydują o ciagłym poszukiwaniu nowych metod diagnozowania oraz sposobów wyznaczania stanu diagnostycznego w procesie eksploatacji.

\subsection{Prognozowanie stanu}

Integralnym elementem procesu diagnozowania stanu jest prognozowanie, czyli przewidywanie stanów maszyny, które zaistnieją w przyszłości. Każdorazowo więc, wyznaczony model: stan-symptom lub często stan-czas eksploatacji maszyny, powinien mieć nie tylko właściwości wyjaśniające naturę przekształcenia, lecz także właściwości predykcyjne umożliwiające przewidywanie zmian stanu maszyny. Ma to szczególne znaczenie dla maszyn krytycznych, których unieruchomienie może być przyczyną znacznych strat materialnych, a nawet zagrożenia zdrowia i życia ludzkiego. Rozpoznanie przewidywanych zmian stanu w określonym horyzoncie czasowym jest naogół nieodzowne dla uzyskania właściwej efektywności działania maszyn, pozwalających użytkownikowi podejmować racjonalne decyzje dotyczące terminu i zakresu niezbędnych prac obsługowych [5].

Metody prognozowania stanów badanego obiektu można podzielić na:

- metody intuicyjne

- metody matematyczne.

Metody intuicyjne obejmują rozległy obszar rozciagający się od wypowiedzi poszczególnych fachowców i ekspertyz zbiorowych opracowanych wg zasady przegłosowania, aż do metody dyskusji panelowych i metody delfickiej.

Ankietowanie grupy specjalistów bywa prowadzone w nadziei, że niektóre błędy zawarte w opiniach indywidualnych ulegną ,przegłosowaniu” w opinii zbiorowej. Dyskusje panelowe zmuszają grupę ekspertów do bezpośrednich kontaktów wzajemnych, co 
umożliwia konstruktywną wymianę poglądów i możliwość uściślenia podejmowanych decyzji [4].

$\mathrm{W}$ matematycznych metodach prognozowania stanów nadzorowanych maszyn, wszelkie subiektywne przesłanki dotyczące badania zmian stanów są formułowane w języku matematycznym, w oparciu o dostępne modele matematyczne [4].

Realizacja prognoz w systemach diagnostycznych uwarunkowana jest procesem identyfikacji trendu zmian wartości kontrolowanych symptomów. Przydatność różnych formalizacji prognostycznych dla systemów diagnostycznych pozwala pogrupować je w następujące grupy [4]:

- klasyczna ekstrapolacja wartości szeregów czasowych

- adaptacyjne modele trendu

- autonomiczna ekstrapolacja procesów stochastycznych

- modele obserwatora zmian monitorowanego stanu dynamicznego, opisanego stochastycznymi równaniami różniczkowymi

- statystyczne modele zmian symptomowych.

W zastosowaniach praktycznych warto wesprzeć się na ocenie metod prognozowania przeprowadzonej w zależności od zachowania się trendu nadzorowanego symptomu wyróżniającej dwa przypadki:

- znany lub łatwy do wyznaczenia a posteriori z obserwacji modelu trendu symptomu

- nie znany i prawie niemożliwy do wyznaczenia model trendu.

\section{WĘZEL LOŻYSKOWY - WYMAGANIA}

Prawidłowe współdziałanie elementów tworzących węzeł łożyskowy pojazdu szynowego zależy od poprawnego wykonania elementów składowych jak i ich odpowiedniego montażu.

\subsection{Mażnica}

Norma EN 12082:2008 [10] określa zasady i metody dotyczące badań eksploatacyjnych zespołów maźnic $\mathrm{z}$ łożyskami tocznymi zgodnymi $\mathrm{z}$ EN 12080:2008 [8] oraz ze smarami zgodnymi z EN 12081:2008 [9].

Norma została opracowana, w celu ustalenia badań eksploatowanych maźnic stosowanych we wszystkich typach taboru kolejowego i zapewnienia ich przydatności w użytkowaniu, tj. dostosowania zespołu złożonego z korpusu, łożysk, uszczelnień i smaru do wymagań eksploatacyjnych.

Badania prowadzone są $\mathrm{w}$ dwóch etapach:

- etap I - „badanie stanowiskowe”, które polega na umieszczeniu dwóch maźnic na stanowisku badawczym i poddaniu ich wielokrotnym cyklom obciążenia, wynikającym z warunków eksploatacyjnych pojazdów wyposażonych w te maźnice
- etap II - „badania terenowe” polegające na monitorowaniu wystarczająco dużej próbki maźnic w czasie długodystansowej jazdy pojazdów w eksploatacji.

Oba etapy należy wykonywać na kompletnych maźnicach.

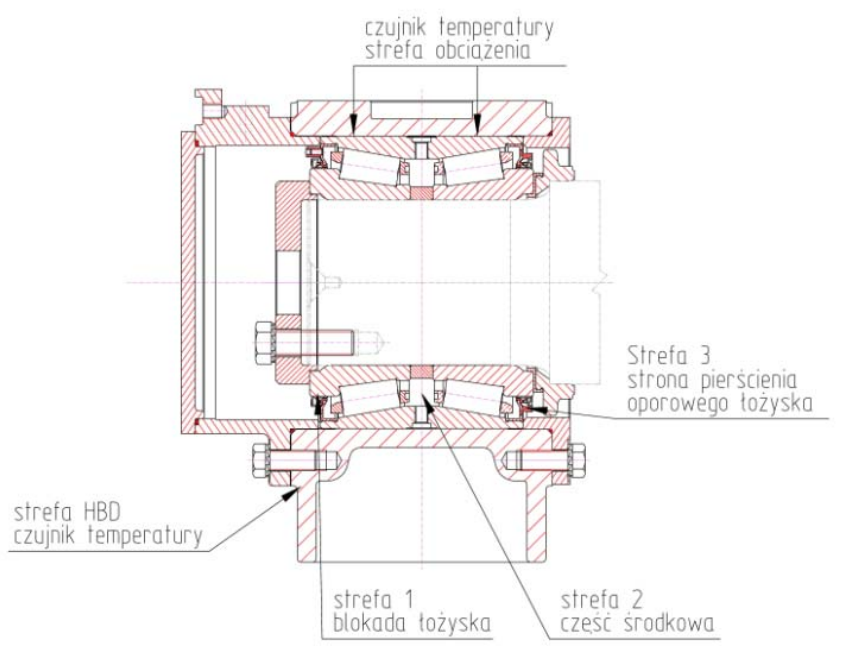

Rys. 3 Strefy czujników temperatury i próbek smaru [1]

Kryteria dopuszczenia maźnicy do ruchu zawarte są również w karcie UIC 515-5 [6].

Podjęte badania maźnic zestawów kołowych wszystkich rodzajów pojazdów służą do ustalenia zdolności do działania, to znaczy będzie przebadane, czy [6]:

- cała część, składająca się z korpusu maźnicy, łożysk tocznych, uszczelnień i smaru odpowiada wymaganiom użytkowym

- łożyska toczne będą smarowane przepisowo i dla długiego czasu stosowane

- maźnice są wodoszczelne.

Badanie to obejmuje trzy etapy:

- etap I - obejmuje badanie szczelności na stanowisku badawczym

- etap II - polega na badaniu na stanowisku badawczym działania łożysk w zakresie symulowanej długiej jazdy na trasie kolejowej

- etap III - obejmujący wypróbowanie ruchowe w pojazdach za pomocą wystarczającej liczby prób łożysk tocznych dotyczących sprawności biegowej; ze względów bezpieczeństwa etap ten przeprowadzany jest $\mathrm{z}$ tylko jeżeli wyniki obu innych etapów były zadowalające.

Kryteria stawiane maźnicy obejmują również jej zabudowę na wózku i odnosi się to do widoczności maźnic dla stałych urządzeń do wykrywania przegrzanych maźnic. Karta UIC 510 [7] zawiera szereg przepisów dotyczących detekcji dla pojazdów jak również przepisów HOA dla urządzeń kolejowych. 


\begin{tabular}{|c|c|c|}
\hline \multicolumn{3}{|c|}{ Kryteria temperaturowe } \\
\hline charakterystyka & \multicolumn{2}{|c|}{ wymagania } \\
\hline $\begin{array}{l}\text { maksymalna temperatura łożyska w strefie obciążenia, w czasie } \\
\text { pierwszych } 20 \text { jazd elementarnych, przy temp. otoczenia } 20^{\circ} \mathrm{C}\end{array}$ & \multicolumn{2}{|c|}{$\leq 100^{\circ} \mathrm{C}$} \\
\hline $\begin{array}{l}\text { maksymalna temperatura łożyska w strefie obciążenia w czasie } \\
\text { każdej jazdy elementarnej z wyłączeniem pierwszych } 20 \text { jazd, } \\
\text { przy temperaturze otoczenia } 20^{\circ} \mathrm{C}\end{array}$ & \multicolumn{2}{|c|}{$\begin{array}{c}\leq 100^{\circ} \mathrm{C} \\
\text { dla maksimum } 1 \% \text { jazd elementarnych } \\
\text { dopuszcza się temperaturę maksymalną w } \\
\text { granicach od } 90^{\circ} \mathrm{C} \text { do } 100^{\circ} \mathrm{C}\end{array}$} \\
\hline $\begin{array}{c}\text { maksymalna temperatura w strefie odczytu HBD w czasie } \\
\text { pierwszych } 20 \text { jazd elementarnych, przy temperaturze otoczenia } \\
20^{\circ} \mathrm{C}\end{array}$ & \multicolumn{2}{|c|}{$\leq 80^{\circ} \mathrm{C}$} \\
\hline $\begin{array}{c}\text { maksymalna temperatura w strefie odczytu HBD w czasie } \\
\text { każdej jazdy elementarnej z wyłączeniem pierwszych } 20 \text { jazd, } \\
\text { przy temperaturze otoczenia } 20^{\circ} \mathrm{C}\end{array}$ & \multicolumn{2}{|c|}{$\begin{array}{c}\leq 70^{\circ} \mathrm{C} \\
\text { dla maksimum } 1 \% \text { jazd elementarnych } \\
\text { dopuszcza się temperaturę maksymalną w } \\
\text { granicach od } 70^{\circ} \mathrm{C} \text { do } 80^{\circ} \mathrm{C} \\
\end{array}$} \\
\hline \multirow[b]{2}{*}{$\begin{array}{c}\text { maksymalna różnica temperatury pomiędzy dwiema } \\
\text { maźnicami, zarejestrowana równocześnie w strefach obciążenia } \\
\text { w czasie każdej jazdy elementarnej, } \mathrm{z} \text { wyłączeniem pierwszych } \\
20 \text { jazd, gdy maksymalna temperatura bardziej gorącej maźnicy } \\
\text { w strefie obciążenia jest } \geq 50^{\circ} \mathrm{C}\end{array}$} & $\mathrm{V} \leq 200 \mathrm{~km} / \mathrm{h}$ & $\mathrm{V}>200 \mathrm{~km} / \mathrm{h}$ \\
\hline & $\begin{array}{c}\leq 15^{\circ} \mathrm{C} \\
\text { dla maksimum } 1 \% \\
\text { jazd elementarnych } \\
\text { dopuszcza się } \\
\text { temperaturę } \\
\text { maksymalną } \mathrm{W} \\
\text { granicach od } 15^{\circ} \mathrm{C} \text { do } \\
25^{\circ} \mathrm{C} \\
\end{array}$ & $\begin{array}{c}\leq 20^{\circ} \mathrm{C} \\
\text { dla maksimum } 1 \% \\
\text { jazd elementarnych } \\
\text { dopuszcza się } \\
\text { temperaturę } \\
\text { maksymalną } \mathrm{W} \\
\text { granicach od } 20^{\circ} \mathrm{C} \text { do } \\
25^{\circ} \mathrm{C}\end{array}$ \\
\hline $\begin{array}{l}\text { maksymalna różnica temperatury między dwiema maźnicami, } \\
\text { zarejestrowana równocześnie w strefach odczytu HBD w czasie } \\
\text { każdej jazdy elementarnej, gdy maksymalna temperatura } \\
\text { bardziej gorącej maźnicy w strefie obciążenia jest } \geq 50^{\circ} \mathrm{C}\end{array}$ & $\begin{array}{c}\leq 15^{\circ} \mathrm{C} \\
\text { dla maksimum } 1 \% \\
\text { jazd elementarnych } \\
\text { dopuszcza się } \\
\text { temperature } \\
\text { maksymalną } \mathrm{W} \\
\text { granicach od } 15^{\circ} \mathrm{C} \text { do } \\
25^{\circ} \mathrm{C}\end{array}$ & $\begin{array}{c}\leq 20^{\circ} \mathrm{C} \\
\text { dla maksimum } 1 \% \\
\text { jazd elementarnych } \\
\text { dopuszcza się } \\
\text { temperaturę } \\
\text { maksymalną } \mathrm{W} \\
\text { granicach od } 20^{\circ} \mathrm{C} \text { do } \\
25^{\circ} \mathrm{C}\end{array}$ \\
\hline $\begin{array}{l}\text { maksymalna różnica temperatury każdej maźnicy, } \\
\text { zarejestrowana w strefie obciążenia między dwiema kolejnymi } \\
\text { jazdami elementarnymi, z wyłączeniem pierwszych } 20 \text { jazd }\end{array}$ & $\begin{array}{c}\leq 15^{\circ} \mathrm{C} \\
\text { dla maksimum } 1 \% \\
\text { jazd elementarnych } \\
\text { dopuszcza się } \\
\text { temperature } \\
\text { maksymalną } \mathrm{W} \\
\text { granicach od } 15^{\circ} \mathrm{C} \text { do } \\
25^{\circ} \mathrm{C}\end{array}$ & $\begin{array}{c}\leq 20^{\circ} \mathrm{C} \\
\text { dla maksimum } 1 \% \\
\text { jazd elementarnych } \\
\text { dopuszcza się } \\
\text { temperaturę } \\
\text { maksymalną } \mathrm{w} \\
\text { granicach od } 20^{\circ} \mathrm{C} \text { do } \\
25^{\circ} \mathrm{C}\end{array}$ \\
\hline \multicolumn{3}{|c|}{ Kryteria mechaniczne i fizyko-chemiczne } \\
\hline \multicolumn{3}{|c|}{ 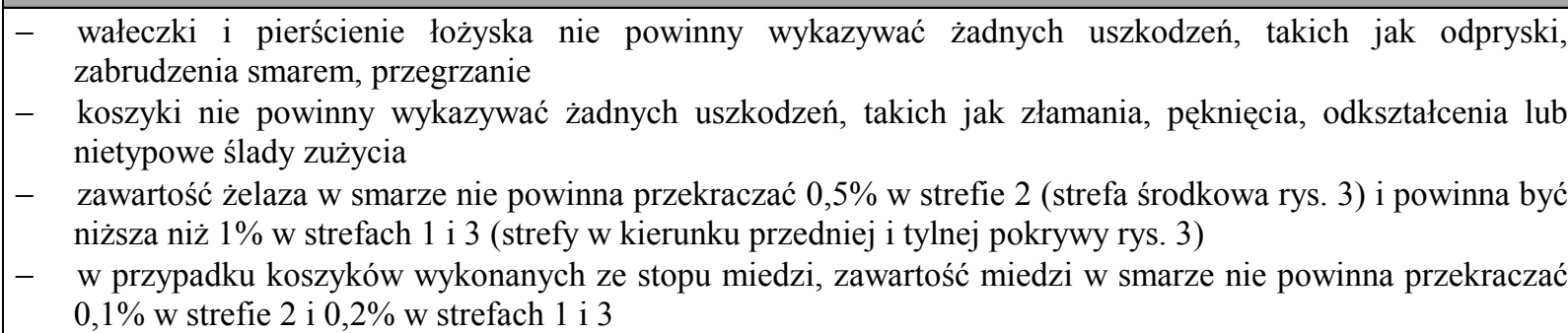 } \\
\hline
\end{tabular}

\section{2 ŁOŻYSKA}

\subsubsection{Uwagi ogólne}

Łożyska toczne, będące jednym z elementów węzła maźnicznego, są bardzo precyzyjnymi elementami, których żywotność bezpośrednio wpływa na ich osiągi. Rzeczywista ocena żywotności łożysk uzależniona jest od wielu czynników. Przedwczesne uszkodzenia łożysk powodują kosztowne przestoje maszyn, czasem nawet $\mathrm{z}$ bardzo poważnymi konsekwencjami. Optymalizacja okresu żywotności łożyska ma swój początek we właściwym jego wyborze. Odpowiedni dobór łożyska uwzględniający stan pracy, obciążenia, sztywność, środowisko pracy powoduje zwiększenie jego żywotności. 
Łożyska pochodzące od renomowanych producentów są wytwarzane zgodnie $\mathrm{z}$ najnowszą technologią $\mathrm{i}$ podlegaja rygorystycznym procedurom zapewnienia jakości. Niemniej jednak celem zapewnienia optymalnej żywotności łożysk, należy zwrócić szczególną uwagę na następujące kwestie:

- właściwe składowanie

- staranny montaż i demontaż

- odpowiednie smarowanie i przesmarowywanie

- odpowiednie monitorowanie warunków pracy

- wykonywanie we właściwym czasie czynności obsługowych oraz dobre szkolenie personelu [13].

\subsubsection{Zasady przechowywania lożysk}

Wszystkie łożyska powinny być składowane w ich oryginalnym opakowaniu do czasu montażu. Powinny być trzymane w czystym, nie wilgotnym otoczeniu przy w miarę stabilnej pokojowej temperaturze. Łożyska toczne powinny być składowane z dala od kurzu, wody i agresywnych chemikaliów. Wibracje i wstrząsy mogą trwale mechanicznie uszkodzić łożyska i z tego względu łożyska nie mogą być na nie narażone podczas transportu i składowania.

W zasadzie wszystkie łożyska powinny być składowane na płasko. Szczególnie łożyska większe, a tym samym cięższe mogą się zdeformować pod własnym ciężarem, kiedy zostaną postawione pionowo i pozostawione tak przez dłuższy czas. Należy zwrócić uwage na składowanie łożysk ze smarem. W ciągu długiego okresu składowanie smar $\mathrm{z}$ takich łożysk może zmienić swoją konsystencję. $Z$ tego względu okres składowania łożysk powinien być kontrolowany przez system FIFO (First In First Out pierwsze przyszło pierwsze wyszło) [13].

Prawidłowe magazynowanie łożysk tocznych wiąże się z zapewnieniem odpowiedniej czystości. Jak już wcześniej wspomniano łożyska toczne są elementami wykonanymi $\mathrm{z}$ dużą dokładnością i precyzją. Powierzchnia styku łożyska $\mathrm{z}$ osią charakteryzuje się dużą gładkością (rzędu $10^{-7} \div 10^{-4} \mathrm{~mm}$ ). Oznacza to, że warstwa styku jest miejscem newralgicznym, które jest wrażliwe na uszkodzenia.

Grubość filmu olejowego pomiędzy powierzchnią styku łożyska $z$ osią ma zwykle grubość od $0,2 \div 1 \mu \mathrm{m}$. Zanieczyszczenia, których cząsteczki mają większy rozmiar od warstwy smarującej, mogą zostać wtłoczone przez elementy toczne, powodując miejscowe naprężenia $\mathrm{w}$ stali łożyskowej, i w końcu spowodować przedwczesne zmęczenie materiału. Zwykły kurz $\mathrm{z}$ otoczenia ma rozmiar ziarna o wielkości do $0,1 \mathrm{mi}-$ kronów, co już może uszkodzić łożysko [13].

\subsubsection{Montaż i demontaż łożysk}

Montaż i demontaż łożysk powinien być przeprowadzany $\mathrm{z}$ wykorzystaniem odpowiednich narzędzi. Zły montaż może prowadzić do uszkodzenia łożyska oraz w konsekwencji do wykolejenia pojazdu. Istnieją udokumentowane przypadki wypadków kolejowych, które były konsekwencją uszkodzenia łożyska poprzez jego nieodpowiedni montaż. Ze względu na fakt, iż montaż łożyska może następować w różnym otoczeniu, należy zwrócić szczególną uwagę, aby zapewnić optymalne warunki. Przede wszystkim montaż należy wykonywać zgodnie $\mathrm{z}$ obowiązującą dokumentacją producenta (dokumentacja konstrukcyjna, instrukcje montażu i demontażu łożysk itp.)

W zależności od zastosowania, rozmiaru oraz przede wszystkim typu łożyska należy wybrać odpowiednią metodę montażu - mechaniczną, termiczną lub hydrauliczną oraz odpowiednie narzędzia. Siły użyte do montowania łożysk nie powinny nigdy być wywierana poprzez elementy toczne. Mogłoby to łatwo prowadzić do miejscowego nadmiernego obciążenia $\mathrm{w}$ obszarze styku elementów tocznych oraz bieżni, co z kolei powoduje przedwczesne uszkodzenia łożysk [13].

Powierzchnie łożysk nie powinny być nigdy uderzane bezpośrednio żadnymi utwardzonymi narzędziami. Może to powodować pęknięcie lub odłupanie pierścienia łożyska. Zawsze należy przestrzegać instrukcji dostawcy odpowiedniego wyposażenia montażowego.

Podczas montażu/demontażu łożyska należy zachować odpowiednie procedury wskazane przez producenta. Ponadto przy demontażu łożyska należy zwrócić uwagę na elementy współpracujące (korpus, oś) celem znalezienia ewentualnego ich uszkodzenia.

\subsubsection{Trwałość łożyska}

Na ogół łożyska toczne są szczególnie trwałe choć nie mają one nieograniczonej żywotności. Tak jak wszystkie inne ważne elementy w mechanizmie, powinny być one regularnie sprawdzane i poddawane czynnościom obsługowym. To, jak często należy przeprowadzać kontrole i wykonywać czynności obsługowe, zależy od ważności danego zastosowania oraz warunków roboczych poszczególnych urządzeń.

Doświadczenia praktyczne wykazały, że pozornie identyczne łożyska toczne pracujące w identycznych warunkach, niekoniecznie uzyskają taką samą trwałość zmęczeniową. Znormalizowane metody obliczenia trwałości pomagają dokonać opartego na nauce wyboru wielkości łożyska do określonego zastosowania. Przemysł zwraca się w stronę znormalizowanych obliczeń żywotności z dobrego powodu: w rzeczywistości niepraktycznie jest z perspektywy czasu i kosztów przeprowadzanie badania wielu łożysk do określonej aplikacji, w specyficznych warunkach pracy, z wymaganym poziomem ufności [14].

Rozwój standardu obliczeń zmierzał w kierunku udoskonalenia metod wyznaczania trwałości tak, aby można było $z$ większą dokładnością przewidzieć rzeczywistą żywotność w danej aplikacji, przy założeniu 
określonych parametrów pracy: innymi słowy, dokładniejsze dopasowanie trwałości obliczeniowej do uzyskanej trwałości eksploatacyjnej. Ostatnie osiągnięcia naukowe w zakresie produkcji łożysk, trybologii, rozwoju materiałów, monitorowania stanu łożysk przez użytkowników końcowych oraz dostęp do technik i urządzeń obliczeniowych doprowadziły do uzyskania możliwości wykonywania bardziej złożonych i dokładniejszych obliczeń żywotności łożysk [14].

Zgodnie z [11] trwałość łożyska definiuje się następująco:

- trwałość - dla pojedynczego łożyska tocznego liczba obrotów wykonywanych przez jeden z pierścieni łożyska względem drugiego pierścienia do wystapienia pierwszych widocznych objawów zmęczenia materiału jednego z pierścieni lub elementów tocznych

- trwałość nominalna $\left(\mathbf{L}_{10}\right)-\mathrm{w}$ odniesieniu do pojedynczego łożyska lub grupy łożysk pozornie identycznych, pracujących w takich samych warunkach, jest to trwałość odpowiadająca niezawodności $90 \%$, przy obecnie powszechnie stosowanym materiale i jakości wytwarzania oraz normalnych warunkach pracy

- trwałość modyfikowana - trwałość uzyskana przez skorygowanie trwałości nominalnej dla żądanego poziomu niezawodności, specjalnych własności materiału i warunków pracy.

Ponadto w pracy [8] można znaleźć dodatkowe określenia trwałości:

- trwałość średnia $\left(\mathbf{L}_{10}\right)$ - w przybliżeniu pięciokrotnie większa od obliczeniowej trwałości nominalnej

- trwałość eksploatacyjna - rzeczywista trwałość osiagana przez łożysko w warunkach pracy do momentu jego uszkodzenia lub gdy konieczna jest wymiana łożyska $\mathrm{z}$ innych powodów

- trwałość dokumentacyjna - generalnie jest to trwałość nominalna $\mathrm{L}_{10}$, a u jej podstaw leży doświadczenia producenta $\mathrm{z}$ podobnymi aplikacjami.

Dobór łożyska jest zwykle dokonywany w oparciu o trwałość łożyska i modele zmęczenia materiału współpracujących powierzchni tocznych służące do wyznaczenia żywotności. Dlatego wstępny dobór wielkości łożyska do danej aplikacji zazwyczaj rozpoczyna się od porównania nośności łożyska z przyłożonymi obciążeniami, które powodują zmęczenie materiału, wywołując naprężenia mające wpływ na trwałość eksploatacyjną i niezawodność łożyska. Niezależnie od siebie muszą zostać sprawdzone warunki obciążenia dynamicznego i statycznego.
Nominalna nośność dynamiczna jest przyjmowana do obliczeń trwałości łożysk obciążonych dynamicznie, to znaczy łożysk, które obracają się pod obciążeniem. Nośność zdefiniowana w ISO 281 określa obciążenie łożyska, przy którym łożysko uzyska trwałość nominalną $\left(\mathrm{L}_{10}\right)$ równą jeden milion obrotów. Obciążenia dynamiczne powinny zostać sprawdzone na podstawie reprezentatywnego cyklu pracy lub spektrum obciążeń działających na łożysko, włącznie z wartościami szczytowymi (wysokimi), które mogą wystapić [14].

Nominalna nośność statyczna jest wykorzystywana do obliczeń, jeżeli łożyska obracają się z prędkościami mniejszymi niż $10 \mathrm{obr} / \mathrm{min}$, wykonują bardzo wolne ruchy oscylacyjne lub w pewnych okresach czasu pozostają nieruchome pod obciążeniem. Obciążenia statyczne to nie tylko siły przyłożone do łożyska znajdującego się w stanie spoczynku lub wykonującego powolny ruch obrotowy. Należy także uwzględnić statyczny współczynnik bezpieczeństwa wynikający z działania wysokich obciążeń udarowych (obciążeń występujących bardzo krótko). Nadmierne obciążenia statyczne mogą uszkodzić łożysko powodując odkształcenia plastyczne w miejscach styku elementów tocznych z bieżniami [14].

Obciążenia działające na łożysko można obliczyć zgodnie z zasadami mechaniki klasycznej, jeżeli znane są siły zewnętrzne lub można je wyznaczyć. Przykładowo, te obciążenia zewnętrzne mogą obejmować siły pochodzące od przenoszenia napędu, siły robocze lub siły bezwładności .Przy obliczaniu elementów składowych obciążenia pojedynczego łożyska, przyjmuje się, że wał jest belką na sztywnych podporach, wolnych od momentu utwierdzenia. W podstawowych obliczeniach katalogowych lub obliczeniach uproszczonych zazwyczaj nie uwzględnia się odkształceń sprężystych łożyska, oprawy lub korpusu maszyny, ani momentów powstających w łożyskach w wyniku ugięcia wału. Historycznie w celu uproszczenia standaryzowane metody obliczania nośności i obciążeń równoważnych są oparte na podobnych założeniach.

Ponieważ trwałość pojedynczego łożyska może być przewidywana tylko statystycznie, szczególnie ważne jest uwzględnianie, że obliczenia trwałości odnoszą się do całej populacji łożysk i założonego poziomu niezawodności. Trwałość nominalna $\mathrm{L}_{10}$ dotyczy niezawodności $90 \%$ łożysk wykonanych z materiału wysokiej jakości, charakteryzujących się dobra jakością wykonania i pracujących w normalnych warunkach [14].

Oczywiście w praktyce trwałość nominalna może znacznie różnić się od rzeczywistej trwałości eksploatacyjnej w danej aplikacji. Przykładowo, opublikowane wyniki pokazały, że faktyczna uzyskana w wyniku testów trwałość może różnić się względem trwałości nominalnej prawie pięciokrotnie. „Trwałość eksploatacyjna" wyraża faktyczną żywotność łożyska 
w prawdziwych warunkach roboczych do momentu jego uszkodzenia. „Trwałość eksploatacyjna” bardziej uwydatnia, że uszkodzenia łożysk mogą być wynikiem ,przyczyn pierwotnych” a nie zmęczenia materiału łożyska. Kiedy łożysko ulega uszkodzeniu, w większości spotykanych obecnie przypadków przyczyną są nieprawidłowo wysokie naprężenia w łożysku, będące rezultatem złych warunków pracy. Przykładami „przyczyn pierwotnych” powodujących uszkodzenia są zanieczyszczenia, zużycie, niewspółosiowość, korozja, uszkodzenia montażowe, smarowanie lub system uszczelniający [14].

Postępy w nauce i technice łożyskowej na przestrzeni lat spowodowały, że nastapiło udoskonalenie konstrukcji i procesu produkcji łożysk, zapewniające wydłużenie trwałości łożysk i zmniejszenie ich wrażliwości na ciężkie warunki pracy. Rozwijane były metody obliczeniowe tak, aby dokładniej można było przewidzieć trwałość eksploatacyjną łożysk. Norma ISO 281:1990 określająca trwałość nominalną i sposób jej obliczania (ISO 281) została zmodyfikowana równolegle do tych zmian, gdyż producenci i użytkownicy łożysk powszechnie zaakceptowali i zastosowali nowsze technologie.

Trwałość łożyska obliczana zgodnie z nowymi metodami znacznie zwiększa w chwili obecnej możliwość przewidywania przez użytkownika rzeczywistej trwałości eksploatacyjnej łożyska przy znanych warunkach pracy.

To prowadzi do wielu korzyści [14]:

- możliwość zastosowania łożyska o mniejszych wymiarach gabarytowych przy pracy w dobrych warunkach, dzięki czemu zmniejsza się tarcie, zużycie energii i wagę

- dobór sposobu smarowania i stopnia filtracji pozwala maksymalnie wydłużyć trwałość łożyska i systemu

- w kontrolowanych warunkach pracy można wydłużyć czas gwarancji lub międzyobsługowe okresy pracy

- możliwość lepszej oceny wpływu parametrów pracy na poszczególne rodzaje i konstrukcje łożysk.

W związku z tym, że obliczenia trwałości łożysk zawierają pewne ryzyko należy zwróć uwagę na następujące zagrożenia:

- wyniki obliczeń są uzależnione od warunków pracy: obciążenia, temperatury, warunków smarowania i zanieczyszczenia; jeżeli zostaną przyjęte nieprawidłowe założenia do doboru łożyska, może to prowadzić do przedwczesnych problemów z łożyskiem

- metodologia i obliczenia zakładaja, że łożyska mają nowoczesną konstrukcję, do ich wyrobu są stosowane najnowsze procesy produkcyjne i materiały zgodne $\mathrm{z}$ wymaganiami technicz- nymi dla stali łożyskowej

- przyjmuje się, że łożyska są montowane i obsługiwane prawidłowo.

Informacje $\mathrm{i}$ wsparcie $\mathrm{z}$ doświadczonych źródeł posiadających odpowiednią wiedzę techniczną i znajomość zagadnień łożyskowych może pomóc użytkownikom w uzyskiwaniu założonej trwałości ich łożysk.

\subsubsection{Uszkodzenia podczas eksploatacji}

Najczęściej nie można bezpośrednio obserwować łożysk tocznych podczas eksploatacji. Jednak w większości wypadków na podstawie odgłosów wydawanych przez łożysko, drgań, temperatur i smarowania można ocenić, czy mogą wystąpić zakłócenia i jakiego rodzaju. Typowe cechy uszkodzeń i ich przyczyny sa podane w tabeli 2 [12].

Powyższe przyczyny powodują konkretne uszkodzenia pozostawiając specyficzny ślad w uszkodzonym łożysku. Badając i prowadząc szczegółowe oględziny uszkodzonego łożyska można wyciągnąć wnioski, co do przyczyny uszkodzenia i podjęć właściwe działania zapobiegawcze.

O uszkodzeniu łożyska świadczą nie tylko pozostawione na nim ślady. Istnieje szereg symptomów, które świadczą o możliwości poważnego uszkodzenia łożysk. Do grupy tej należy zaliczyć [2]:

\section{Przegrzanie łożyska}

Przyczynami podwyższonej temperatury pracy łożyska mogą być:

- nieodpowiedni rodzaj smaru plastycznego lub oleju w danych warunkach roboczych

- zbyt niski poziom oleju

- zbyt mało smaru w oprawie

- zbyt wysoki poziom oleju

- mały luz łożyska wskutek nagrzewania się łożyska poprzez wał

- odkształcenie oprawy, nierówna powierzchnia podparcia

- ocierania uszczelnienia lub odrzutników oleju o elementy nieruchome

- zatkane kanały powrotne oleju

- zbyt mały luz łożyska wskutek nadmiernego wydłużania się wału, zbyt silnie dokręcona nakrętka tulei

- niewyważenie elementów wirujących

- zbyt duży otwór w oprawie

- niewspółosiowe ustawienie wałów.

\section{Hałas lożyska}

Zmiana charakteru i poziomu hałasu węzła łożyskowego może wynikać z następujących zdarzeń:

- niewystarczające smarowanie wynikające np. $\mathrm{Z}$ nieodpowiedniego dobrania smaru lub oleju w danych warunkach roboczych łożyska

- $\quad$ zbyt niski poziom oleju 


\begin{tabular}{|c|c|c|}
\hline $\begin{array}{l}\text { Uszkodzenia } \\
\text { Zluszczenia }\end{array}$ & Przyczyny & Kroki zapobiegawcze \\
\hline $\begin{array}{lr}\text { powierzchnia bieżni wykazuje } \\
\text { ślady zużycia. } & \text { W dalszej } \\
\text { eksploatacji } & \text { występu-ją } \\
\text { wyraźnie } & \text { widoczne } \\
\text { wykruszenia } & \end{array}$ & $\begin{array}{l}\text { - za duże obciążenie lub złe } \\
\text { obchodzenie się z łożyskiem } \\
\text { - nieprawidłowy montaż } \\
\text { - niewystarczająca dokładność } \\
\text { osadzeń wału i oprawy } \\
\text { - za mały luz } \\
\text { - cząstki obce } \\
\text { - korozja } \\
\text { spadek twardości z powodu zbyt } \\
\text { wysokich temperatur roboczych }\end{array}$ & $\begin{array}{l}\text { - } \text { sprawdzić obciążenie łożyska } \\
\text { - wybrać inny rodzaj łożyska } \\
\text { - sprawdzić luz łożyska } \\
\text { - } \text { sprawdzić dokładność wykonania } \\
\text { wału i oprawy } \\
\text { - sprawdzić dobór } \\
\text { współpracujących z łożyskiem części } \\
\text { - sprawdzić metodę montażu } \\
\text { - sprawdzić smar i sposób } \\
\text { smarowania }\end{array}$ \\
\hline $\begin{array}{l}\text { Blokowanie } \\
\text { temperatura łożyska stale } \\
\text { wzrasta, łożysko zmienia barwę } \\
\text { względnie łożysko się blokuje }\end{array}$ & $\begin{array}{l}\text { - za mały luz łożyskowy ew. } \\
\text { wskutek błędów kształtu czopów } \\
\text { - niewystarczające smarowanie } \\
\text { lub niewłaściwie dobrany smar } \\
\text { - za wysokie obciążenie (zbyt } \\
\text { duży nacisk) } \\
\text { - skośne obciążenie elementów } \\
\text { tocznych }\end{array}$ & $\begin{array}{l}\text { - } \text { sprawdzić luz łożyskowy } \\
\text { - sprawdzić środki smarowne } \\
\text { metodę smarowania } \\
\text { - sprawdzić warunki eksploatacji } \\
\text { - skorygować niewspółosiowość } \\
\text { - sprawdzić otoczenie łożyska } \\
\text { pasowania } \\
\text { sprawdzić metodę montażu }\end{array}$ \\
\hline $\begin{array}{l}\text { Rysy } \boldsymbol{i} \text { karby } \\
\text { miejscowe wykruszenia, } \\
\text { widoczne małe rysy i karby }\end{array}$ & $\begin{array}{l}\text { - zbyt duże obciążenie udarowe } \\
\text { - za ciasne pasowanie } \\
\text { - duże łuszczenia na bieżniach } \\
\text { - rysy ślizgowe } \\
\text { niedopasowanie zaokragleń łożyska } \\
\text { o gniazda, wału niewłaściwe } \\
\text { obchodzenie się z łożyskiem }\end{array}$ & $\begin{array}{l}\text { - sprawdzić warunki eksploatacji } \\
\text { - sprawdzić pasowania materiału } \\
\text { wału względnie oprawy } \\
\text { - sprawdzić sposób montażu i } \\
\text { staranniej obchodzić się z łożyskiem } \\
\text { - sprawdzić smarowanie } \\
\text { sprawdzić metodę montaż }\end{array}$ \\
\hline \multicolumn{3}{|l|}{ Koliste ślady wytarcia } \\
\hline $\begin{array}{l}\text { rysy lub nieregularne koliste } \\
\text { ślady wytarcia pozostawione } \\
\text { przez elementy toczne na } \\
\text { powierzchni bieżni }\end{array}$ & $\begin{array}{l}\text { - wał lub obudowa są } \\
\text { niewystarczającej dokładności } \\
\text { - niewłaściwy montaż } \\
\text { niewystarczająca sztywność wału } \\
\text { lub obudowy } \\
\text { wał wiruje z powodu zbyt dużego } \\
\text { luzu wewnętrznego w łożysku }\end{array}$ & $\begin{array}{l}\text { - sprawdzić luz wewnętrzny w } \\
\text { łożysku } \\
\text { - sprawdzić dokładności wału i } \\
\text { obudowy } \\
\text { - sprawdzić sztywność mocowania } \\
\text { wału i odbudowy }\end{array}$ \\
\hline $\begin{array}{l}\text { Uszkodzenia koszyka } \\
\text { wyłamane nitowania koszyka, } \\
\text { uszkodzenia koszyka. Lączenia } \\
\text { się koszyka rozłączają się lub } \\
\text { łamią }\end{array}$ & $\begin{array}{l}\text { - za duże obciążenie momentem } \\
\text { - za duża prędkość obrotowa lub } \\
\text { przyspieszenie } \\
\text { - niewystarczające smarowanie } \\
\text { - ingerencje siły wewnętrznej } \\
\text { - za duże wibracje } \\
\text { - nieprawidłowy montaż } \\
\text { - za wysoka temperatura robocza } \\
\text { łożyska }\end{array}$ & $\begin{array}{l}\text { - sprawdzić warunki eksploatacji } \\
\text { - sprawdzić sposób smarowania } \\
\text { - dobór koszyka } \\
\text { staranniej obchodzić się z łożyskiem } \\
\text { ocenić sztywność oprawy wału }\end{array}$ \\
\hline \multicolumn{3}{|l|}{ Smarowanie, zacieranie się } \\
\hline $\begin{array}{lrr}\text { powierzchnie } r \text { bieżni } & \text { są } \\
\text { nierówne i wykazują } & \text { ślady } \\
\text { wytarcia pozostawione przez } \\
\text { elementy toczne na powierzchni } \\
\text { bieżni }\end{array}$ & $\begin{array}{l}\text { - niewystarczające smarowanie } \\
\text { - drobnoziarniste cząstki obce } \\
\text { - ukośnie położone wałeczki } \\
\text { wskutek błędów współliniowości } \\
\text { - ruch ślizgowy elementów } \\
\text { tocznych } \\
\text { - zbyt duża chropowatość } \\
\text { powierzchni } \\
\text { zbyt duże obciążenie osiowe }\end{array}$ & $\begin{array}{l}\text { - sprawdzić środek smarowy i system } \\
\text { smarowania } \\
\text { - sprawdzić warunki robocze } \\
\text { - sprawdzić napięcie wstępne łożyska } \\
\text { - poprawić uszczelnienia } \\
\text { - staranniej obchodzić się z łożyskiem }\end{array}$ \\
\hline
\end{tabular}


powierzchni posiada miejscowo lub ogólnie ślady korozji. Ślady rdzy/korozji przy linii podziałowej elementów tocznych
- nieodpowiednie przechowywania

- niewłaściwe opakowanie

- niewłaściwa konserwacja łożyska

- kontakt z wodą, kwasem

- dotykanie gołymi rękoma

warunki
- poprawić warunki składowania łożysk

- poprawić uszczelnienie

- sprawdzić środki smarne

- staranne obchodzenie się $\mathrm{z}$ łożyskiem, unikać kontaktu z nieosłoniętymi rękoma

- poprawić konserwację łożyska unikać wtargnięcia wody, wpływów chemicznych, potu

\section{Ślady zatarcia \\ wskutek korozji stykowej powstaje drobny rdzawy proszek na matowych powierzchniach lub wgniecenia Brinella na bieżni od elementów tocznych}

- niewystarczający wcisk przy wtłaczaniu

- oscylujące mikroruchy

- niewystarczające smarowanie

- obciążenia pulsujące

- wibracje lub drgania w trakcie transportu

- sprawdzić pasowanie i smarowanie łożyska

- pierścieniewewnętrzne

i zewnętrzne transportować osobno

- jeśli pierścienie nie mogą być transportowane osobno, ustawić napięcie wstępne

sprawdzić środek smarowy względnie

zmienić rodzaj łożyska

\begin{tabular}{|c|c|c|}
\hline \multicolumn{3}{|l|}{ Zużycie } \\
\hline $\begin{array}{l}\text { zużycie powierzchni, zmieniona } \\
\text { dokładność kształtu, ślady } \\
\text { zadrapań i szorstkie powierzchnie }\end{array}$ & $\begin{array}{l}\text { - cząstki obce w środku } \\
\text { smarnym } \\
\text { - niewystarczające smarowanie } \\
\text { - przekoszenie wałeczków }\end{array}$ & $\begin{array}{l}\text { - sprawdzić środek smarny i metodę } \\
\text { smarowania } \\
\text { - poprawić uszczelnienia } \\
\text { - skorygować błędy współliniowości }\end{array}$ \\
\hline \multicolumn{3}{|l|}{ Korozja elektrolityczna } \\
\hline $\begin{array}{l}\text { kratery na } \begin{array}{c}\text { bieżniach, } \\
\text { powstawanie } \\
\text { bieżniach }\end{array} \\
\text { rowków na }\end{array}$ & - prąd płynie przez łożysko & $\begin{array}{l}\text { - wykonać mostek prądowy } \\
\text { - zaizolować łożysko }\end{array}$ \\
\hline \multicolumn{3}{|l|}{ Wgniecenia i zadrapania } \\
\hline $\begin{array}{l}\text { zdarcia podczas montażu, } \\
\text { zadrapania spowodowane przez } \\
\text { twarde cząstki obce, wgniecenia } \\
\text { spowodowane } \\
\text { mechanicznymi }\end{array}$ & $\begin{array}{l}\text { - cząstki obce w łożysku } \\
\text { - niestaranne smarowanie } \\
\text { pierścienia wewnętrznego i } \\
\text { zewnętrznego } \\
\text { - nieprawidłowy montaż } \\
\text { niewspółliniowe zamontowanie } \\
\text { części upuszczenie łożyska lub } \\
\text { inne nieostrożne obchodzenie się } \\
\text { z łożyskiem }\end{array}$ & $\begin{array}{l}\text { - staranny montaż } \\
\text { - poprawić czystość na stanowisku } \\
\text { pracy } \\
\text { - sprawdzić czystość na stanowisku } \\
\text { pracy } \\
\text { - sprawdzić czystość wszystkich } \\
\text { części maszyn }\end{array}$ \\
\hline \multicolumn{3}{|l|}{ Pelzanie (ang. Creeping) } \\
\hline $\begin{array}{l}\text { powierzchnie otworu i } \\
\text { powierzchnia gniazda są gładkie } \\
\text { jak lustro lub odbarwione, mogą } \\
\text { być widoczne wżery }\end{array}$ & $\begin{array}{l}\text { - za mały wcisk przy pasowaniu } \\
\text { - tuleja wciągana } \\
\text { niewystarczająco naciagnnięta } \\
\text { - anormalne } \\
\text { termiczne } \\
\text { - } \quad \text { za wysłłużenia } \\
\end{array}$ & $\begin{array}{l}\text { - } \text { sprawdzić pasowanie } \\
\text { - } \text { sprawdzić warunki eksploatacji } \\
\text { - } \text { sprawdzić warunki osadzeń }\end{array}$ \\
\hline \multicolumn{3}{|l|}{ Zmatowienie powierzchni } \\
\hline $\begin{array}{l}\text { powierzchnia bieżni jest matowa, } \\
\text { szorstka i/lub równomiernie } \\
\text { wgłębiona. Powierzchnia pokryta } \\
\text { drobnymi wgnieceniami }\end{array}$ & $\begin{array}{l}\text { - niewystarczające smarowanie } \\
\text { - przeniknięcie do łożyska } \\
\text { obcego zanieczyszczenia }\end{array}$ & $\begin{array}{l}\text { - sprawdzić środek smarny i metodę } \\
\text { smarowania } \\
\text { •poprawić uszczelnienia } \\
\text { - sprawdzić czystość środka } \\
\text { smarnego (filtr może być nadmiernie } \\
\text { zanieczyszczony) }\end{array}$ \\
\hline
\end{tabular}

\section{Luszczenie}

komasowanie drobnych złuszczeń

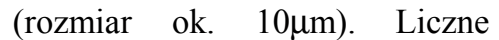

- niewystarczające smarowanie

- przeniknięcie do łożyska

obcego zanieczyszczenia
- sprawdzić środek smarny i metodę smarowania

-poprawić uszczelnienia (aby zapobiec wnikaniu zanieczyszczeń) złuszczeniem (uszkodzenie czesto spotykane w łożyskach wałeczkowych) 
- zbyt mało smaru w oprawie

- zbyt mały luz łożyska wynikający z nagrzewania łożyska poprzez wał, zbyt duża rozszerzalność cieplna pierścienia wewnętrznego

- pojawienie się zanieczyszczeń w oprawie łożyska

- wniknięcie do oprawy łożyska środków przyspieszających korozję

- odkształcenie oprawy łożyska, nierówna powierzchnia podparcia, zbyt mały otwór w oprawie

- ocierania uszczelnień lub odrzutników oleju o elementy nieruchome

- mały luz łożyska wynikający z nadmiernego wydłużenia się wału

- mała średnica wału, tuleja wciągana nie jest wystarczająco dokręcona

- zbyt silnie dokręcona nakrętka tulei wciąganej

- niewyważenie części wirujących

- zbyt duży otwór w oprawie łożyska

- spłaszczenie elementów tocznych na skutek poślizgu

- skrzywienie wału

- odkształcenie uszczelnień łożysk

- drgania spowodowane zbyt dużym luzem roboczym łożyska

- odkształcenie wału lub innych części łożyskowania wskutek ich przegrzania

- obracanie się pierścienia zewnętrznego w powiększonym otworze oprawy

- drgania łożysk podczas postoju.

\section{Drgania}

Poziom drgań uszkodzonych łożysk rosnący wraz $\mathrm{z}$ ich zużyciem może się radykalnie obniżyć tuż przed awarią. We wczesnych stanach degradacji łożyska drgania charakteryzują się dużymi częstotliwościami. W późniejszych stanach rośnie składowa obrotowa drgań oraz wiele jej wielokrotności.

Podwyższony poziom drgań węzłów łożyskowych może wynikać z:

- zabrudzenia łożyska

- odkształcenia oprawy łożyska

- wniknięcia do oprawy łożyska środków przyspieszających korozję

- zbyt małej średnicy wału

- niewyważenia elementów wirujących

- zbyt dużego otworu w oprawie łożyska

- spłaszczenia elementów tocznych na skutek poślizgu

- nierównomiernego obciążenia łożyska na skutek błędu kształtu wału i gniazda oprawy

- skrzywienia wału

- odkształcenia wału pierścienia wewnętrznego

- odkształcenia oprawy i pierścienia zewnętrznego
- niewspółosiowości wałów maszyn

- zbyt dużego luzu roboczego

- obracania się pierścienia zewnętrznego w powiększonym otworze oprawy łożyskowej.

Z powyższego wynika, jak ważny jest odpowiedni dobór łożyska jak i elementów z nim współpracujących. Dobór właściwego łożyska jest zagadnieniem prostym. Procedura rozpoczynająca się od ustalenia rodzaju obciążenia oraz jego charakteru oddziaływania w kolejnych krokach wymaga szczegółowego przewidzenia lub ustalenia istniejących warunków pracy. W przeciwnym wypadku wybór może okazać się niewłaściwy.

\section{ZAKOŃCZENIE}

Obecnie projektowane pojazdy szynowe maja stawiane wysokie wymagania odnośnie sprawności i niezawodności. Wiele $\mathrm{z}$ nich posiada wbudowane systemy diagnostyczne monitorujące newralgiczne miejsca w pojeździe. Systemy te pozwalają usunąć potencjalna usterkę poprzez odpowiednio wczesne jej wykrycie oraz przesłanie informacji do użytkownika. Postęp techniczny oraz stosowanie coraz bardziej zaawansowanych technologii w konstrukcji pojazdów szynowych decyduje o poszukiwaniu nowoczesnych metod diagnostycznych oraz sposobów oceny stanu technicznego pojazdu. Diagnostyka pojazdu nie tylko daje nam informacje o obecnym stanie pojazdu, ale również ma wpływ na optymalizację konstrukcji pojazdu. Miejsca newralgiczne w pojeździe wskazane w procesie diagnozowania mogą być skorygowane podczas modernizacji pojazdu oraz mają wpływ na konstrukcję nowych pojazdów.

W procesie oceny stanu technicznego pojazdu istotną rolę odgrywa również prognozowanie, czyli przewidywanie stanów maszyny, które zaistnieją w przyszłości. Rozpoznanie przewidywanych zmian stanu pojazdu w czasie, pozwala uzyskać informacje o właściwej efektywności działania pojazdu, mającej wpływ na podejmowanie decyzji dotyczącej terminu i zakresu niezbędnych prac obsługowych.

W układach biegowych pojazdów szynowych jednym z newralgicznych miejsc mających wpływ na sprawność pojazdu jest węzeł maźniczy. Ze względu na swoją konstrukcję oraz umiejscowienie maźnica spełnia rolę „nośnika” informacji mających wpływ na stan pojazdu.

Łożyska toczne, będące jednym z elementów węzła maźnicznego, są bardzo precyzyjnymi elementami, których żywotność bezpośrednio wpływa na ich osiągi. Uszkodzenia łożysk przyczyniają się do kosztownych przestojów pojazdu, często z poważnymi konsekwencjami dla właściciela lub użytkownika pojazdu. $\mathrm{Z}$ powyższego wynika jak ważny jest odpowiedni dobór łożyska uwzględniający stan pracy, obciążenia itp. 


\section{LITERATURA}

[1] Antkowiak T.:Węzel łożyskowy. Diagnostyka i prognozowanie. 10.2010. OR 9842 (dokument przechowywany $w$ archiwum IPS ,,Tabor" Poznań)

[2] J. Dwojak, M. Rzepiela,,Diagnostyka i obstuga techniczna łozysk tocznych", Warszawa 2003

[3] Kowalski St., Sowa A., Klasyfikacja metod diagnostyki technicznej stosowanych $w$ zaktadzie napraw taboru kolejowego, Problemy eksploatacji $n$ r.2, 2007

[4] H.Tylicki, Algorytm rozpoznawania stanu maszyn" MOTROL, 2007

[5] B. Źóltowski „Podstawy diagnostyki maszyn”, WUAT-R. 1996

[6] karta UIC 515-5,,Badanie maźnic zestawów kolowych"
[7] karta UIC 510,,Widoczność maźnic zestawów kołowych dla statych urzadzeń do wykrywania przegrzanych maźnic (HOA)"

[8] EN 12080:2008,,Kolejnictwo - Maźnice Lożyska toczne"

[9] EN 12081:2008,,Kolejnictwo - Maźnice Smary"

[10] EN 12082:1998,,Kolejnictwo. Maźnice. Badania eksploatacyjne"

[11] ISO 281:1990,,Łożyska toczne. Nośność dynamiczna i trwatość".

[12] www.albeco.com.pl

[13] www.utrzymanieruchu.pl

[14] www.utrzymanieruchu24.pl 